\title{
Relationship Between Avirulence Gene (avrA) Diversity in Ralstonia solanacearum and Bacterial Wilt Incidence
}

\author{
Alison E. Robertson, ${ }^{1}$ W. Patrick Wechter, ${ }^{1}$ Timothy P. Denny, ${ }^{2}$ Bruce A. Fortnum, ${ }^{3}$ and Daniel A. Kluepfel ${ }^{4}$ \\ ${ }^{1}$ Department of Entomology, Soils and Plant Sciences, Clemson University, Clemson, SC 29634-0377, U.S.A; ${ }^{2}$ Department \\ of Plant Pathology, University of Georgia, Athens 30602-7274, U.S.A; ${ }^{3}$ Pee Dee Research and Education Center, Florence, \\ SC 29506-9706, U.S.A; ${ }^{4}$ United States Department of Agriculture-Agricultural Research Service, Department of Plant \\ Pathology, University of California, Davis 95616, U.S.A.
}

Submitted 2 April 2004. Accepted 30 July 2004.

Bacterial wilt, caused by Ralstonia solanacearum, is a serious disease of tobacco in North and South Carolina. In contrast, the disease rarely occurs on tobacco in Georgia and Florida, although bacterial wilt is a common problem on tomato. We investigated whether this difference in disease incidence could be explained by qualitative characteristics of avirulence gene avrA in the $R$. solanacearum population in the southeastern United States. Sequence analysis established that wild-type avrA has a 792-bp open reading frame. Polymerase chain reaction (PCR) amplification of avrA from 139 $R$. solanacearum strains generated either 792-bp or $\approx 960$-bp DNA fragments. Strains that elicited a hypersensitive reaction (HR) on tobacco contained the 792-bp allele, and were pathogenic on tomato and avirulent on tobacco. All HRnegative strains generated a $\approx 960-b p$ DNA fragment, and wilted both tomato and tobacco. The DNA sequence of avrA in six HR-negative strains revealed the presence of one of two putative miniature inverted-repeat transposable elements (MITEs): a 152-bp MITE between nucleotides 542 and 543, or a 170-bp MITE between nucleotides 461 and 462 or 574 and 575 . Southern analysis suggested that the 170-bp MITE is unique to strains from the southeastern United States and the Caribbean. Mutated avrA alleles were present in strains from 96 and $75 \%$ of North and South Carolina sites, respectively, and only in 13 and $0 \%$ of the sites in Georgia and Florida, respectively. Introduction of the wildtype allele on a plasmid into four HR-negative strains reduced their virulence on both tobacco and tomato. Inactivation of avrA in an HR-positive, avirulent strain, resulted in a mutant that was weakly virulent on tobacco. Thus, the incidence of bacterial wilt of tobacco in the southeastern United States is partially explained by which avrA allele dominates the local $R$. solanacearum population.

Additional keywords: insertion sequence.

Bacterial wilt is a major disease of tobacco in North and South Carolina (Lucas 1975). In contrast, the disease rarely

Corresponding author: D. A. Kluepfel, E-mail: dakluepfel@ucdavis.edu

* The $\boldsymbol{e}$-Xtra logo stands for "electronic extra" and indicates the HTML abstract available on-line contains supplemental material not included in the print edition.

This article is in the public domain and not copyrightable. It may be freely reprinted with customary crediting of the source. The American Phytopathological Society, 2004 occurs on tobacco in Georgia and Florida, although it is common on tomato in tobacco-growing counties (Fortnum and Martin 1998; Kelman and Person 1961). Kelman and Person (1961) found considerable variation in wilt disease severity caused by Ralstonia solanacearum strains from these four states on different hosts. Their investigation revealed that Georgia strains of $R$. solanacearum have low virulence on tobacco, and that bacterial wilt on tomato does not necessarily indicate a hazard for tobacco or peanut production in Georgia. When a wilt-susceptible cultivar of tobacco was planted into a tomato-transplant field in Georgia with a history of $90 \%$ bacterial wilt incidence, not a single plant exhibited wilt symptoms (Kelman and Person 1961). In contrast, R. solanacearum strains from tobacco in North Carolina, South Carolina, Georgia, Florida, and Virginia were highly virulent on both tobacco and tomato in greenhouse tests.

Numerous studies have assessed the genetic diversity of $R$. solanacearum strains collected from diverse geographic areas and host species (Cook et al. 1989). There also have been studies on the phenotypic and genotypic variation of $R$. solanacearum populations within localized geographic regions (Dookun et al. 2001; Gillings and Fahy 1993; Horita and Tsuchiya 2001; Poussier et al. 1999; Smith et al. 1995). Previously we reported that repetitive extragenic palindromic (REP) and enterobacterial repetitive intergenic consensus (ERIC) polymerase chain reaction (PCR) could be used to differentiate $R$. solanacearum populations isolated from different geographical areas of the southeastern United States (Robertson et al. 2001). However, it was not possible to associate a specific genetic marker with either aggressiveness or geographic location. Subsequent to these observations, we hypothesized that, given its potential in mediating plant-pathogen interactions, the avirulence gene avrA may be useful in discriminating $R$. solanacearum populations and explain differences observed in bacterial wilt incidence in the Carolinas and Georgia or Florida.

In $R$. solanacearum AW1, avrA is responsible for eliciting a hypersensitive response (HR) on tobacco (Carney and Denny 1990). AvrA was cloned, and its ability to shift strain K60 from being pathogenic on tobacco to eliciting an HR was demonstrated. The transconjugants also were nonpathogenic on tobacco. Inactivating avrA in AW1 prevented this strain from eliciting an HR on tobacco, but it did not become pathogenic on tobacco. Therefore, $a v r A$ is one factor that restricts the host range of $R$. solanacearum (Carney and Denny 1990). Avirulence genes in a pathogen determine race specificity by limiting the range of host cultivars and, occasionally, host species and genera that the pathogenic strain may attack (Gabriel 1999). Therefore, loss or inactivation of an avirulence gene 
often extends the host range of a pathogen to include plants previously found to be resistant (Kearney and Staskawicz 1990a). However, numerous reports have shown that inactivation of $a v r$ genes eliminates the HR but does not enable the strains to induce disease symptoms on the same host (Leach and White 1996). The objective of this study was to investigate the sequence diversity of avrA in $R$. solanacearum strains from the southeastern United States in relation to geographic distribution and the incidence of wilt disease on tomato and tobacco.

In addition to regulating resistance $(R)$-gene-specific interactions, $a v r$ genes have been reported to contribute to pathogen virulence on susceptible hosts. The first such evidence was provided by Kearney and Staskawicz (1990b), who reported that Xanthomonas campestris pv. vesicatoria containing an inactivated $a v r B s 2$ gene was less virulent on a susceptible pepper cultivar compared with the wild-type strain. In addition, a marker exchange avrBs 2 mutant of $X$. campestris pv. vesicatoria exhibited a 100-fold reduction in its ability to colonize susceptible plant tissue. Similarly, the $a v r E$ gene from Pseudomonas syringae pv. tomato restored pathogenicity to the "disease-specific" locus ( $d s p$ ) mutant strain of Erwinia amylovora that was avirulent on pear fruit (Bogdanove et al. 1998). Although the mechanisms describing these observations are unknown, avr gene products mediate the suppression of inducible host defenses (Abramovitch et al. 2003; Vivian and Gibbon 1997; Yang et al. 2000). When expressed ectopically in plants lacking the corresponding $R$ gene, $a v r$ genes can induce such phenotypes as chlorosis, necrosis, canker formation, cell division, and enlargement and cell death (Kjemtrup et al. 2000). Interestingly, other type III effectors from animal-bacterial pathogens exhibit similar cytotoxic effects on the host cells (van't Slot and Knogge 2002).

Plant resistance to bacterial wilt is often geographically specific (Jack and Robertson 1997; Michel et al. 1996; Prior et al. 1994). It has been hypothesized that environmental conditions and genetic diversity of the pathogen over a wide geographic area may account for these observations. Here we have shown that diversity of the avirulence gene, $a v r A$, impacts the incidence of bacterial wilt as a function of geography.

\section{RESULTS}

\section{AvrA is a novel protein with characteristics}

of effectors secreted by Hrp type III systems.

Previous research indicated that, in pBC73, which contains $4.5 \mathrm{~kb}$ of AW1 genomic DNA, the 5' end of $a v r A$ is within the terminal $200 \mathrm{bp}$ that separate the end of the fragment from a unique internal EcoRI site and that the gene must be less than $2 \mathrm{~kb}$ long (Carney and Denny 1990). A 3.1-kb PstI fragment from $\mathrm{pBC} 73$, which contains avrA, was subcloned into pRK404 to produce pBC738 (Fig. 1A), and a 2.3-kb region was sequenced on both strands (GenBank accession number AY517472). DNA sequence analysis indicated that it has one open reading frame (ORF) with 263 codons and, 214 nucleotides downstream, a second ORF with 305 codons (Fig. 1A). We concluded that the smaller ORF corresponds to avrA, because its $5^{\prime}$ end is appropriately situated, the ORF spans the unique EcoRI site, and its codon usage is similar to all ORFs in the genome of $R$. solanacearum strain GMI1000. The G + C content of $a v r A$ is $60.6 \%$, which is only moderately lower than the $\approx 67 \%$ typical of this species. Seven base pairs upstream of avrA is a potential ribosome binding site, and $69 \mathrm{bp}$ upstream is a near consensus plant-inducible promoter (PIP-box) sequence of TTCGT-N 15 -TTCGT (consensus nucleotides are underlined) (Cunnac et al. 2004; Fenselau and Bonas 1995). A PIP-box is present upstream of three transcriptional units in the hrp gene cluster and six additional avirulence gene homologues in GMI1000 (Cunnac et al. 2004; Fenselau and Bonas 1995; Salanoubat et al. 2002). Five bases downstream of the avrA stop codon is a potential stem-loop sequence that could be a transcriptional terminator. This sequence was used to design PCR primers to amplify a 793-bp fragment that extends from 4 bases upstream of the avrA start codon through the last amino acid codon.

Analysis of the predicted AvrA protein showed it to be very hydrophilic, lacking both a signal peptide and transmembrane domains. No large $\alpha$-helices or $\beta$-sheet structures were predicted, and no motifs were found at an E value $<0.01$ using reverse position-specific BLAST (Altschul et al., 1997). Like

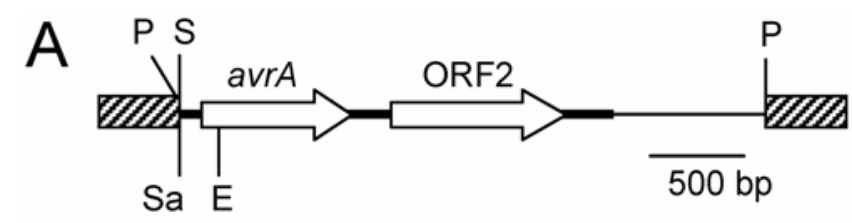

B $\quad A W I$

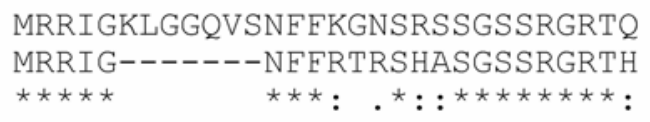

AW1 EVEEGSSRRAARSPSPEFSNLRSRSNSATS GMI EREEGSSGRAARSPSPALSDLPSSP-----

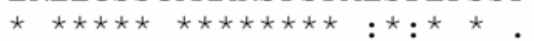

AW1 SPVYSRSNSATSSPVRSRPISTVASPTRED GMI ---------------RSRHVSTVASPTRFD

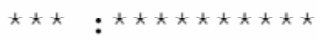

AW1 GRGRVTDPGHIQYQTSEWEREQYG-LSDAI GMI DDGRVTYPGHIQYQTSESERERYPDLAEAV

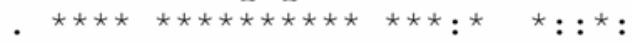

AW1 GHSRYTGYGAPRPERFPVEGHLPNGQYFNV GMI GHSRYTGPGSPRPEREPISGYEPDGQYESV

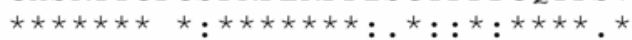

AW1 TGVRGPAINAGDDHVIDHGYASHVIDHGEM GMI TGLRGPAIRSGDDAVIDRQHASHVIDHGEM

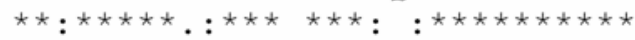

AW1 SYDQAARYREYQSQPVEPSYETSGHDRSNC GMI SDAQAGREMDWQNRSIYPTYETSGWEYSNC

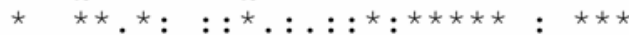

AW1 VHGHAELGREIFGWNIQHDQHATPQDLAEQ GMI VHGHAEVGRSVEGWDVYPDQHARPQDLADQ

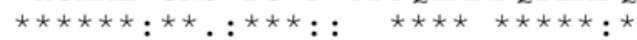

\section{AW1 MRGLRVDGYNSYSSYRNGNDSDSE \\ GMI MGNLRVRNYNSDS------DSDG- $\star . * \star \star . * \star \star \star * \quad \star * \star$.}

Fig. 1. DNA sequence analysis of Ralstonia solanacearum avrA in strain AW1. A, The 3.1-kb PstI fragment of $\mathrm{pBC73}$ that was subcloned into pBlueScript (hatched bands) for use as a sequencing template. The two open arrows represent the complete open reading frames (ORFs) present in the 2.3-kb sequenced region (heavy line). Restriction enzymes abbreviations: E, EcoRI; P, PstI; S, SalI, Sa, Sau3A (only relevant sites are shown). Restriction sites labeled above the figure are in the vector, whereas those below the figure are in the cloned $R$. solanacearum DNA. B, Alignment of AvrA from AW1 with its homolog in strain GMI1000 (ORF number RS04833). Symbols below the alignment indicate identical amino acids (*), conserved substitutions (: and .), and gaps (-). The two proteins were aligned using ClustalW with default settings. 
many type III secreted effectors in $P$. syringae, the N-terminal third of AvrA is amphipathic, rich in serine residues, and low in acidic residues (Guttman et al. 2002; Petnicki-Ocwieja et al. 2002). Also typical of many effectors, the putative AvrA protein has no homolog in GenBank, except for ORF RS04833 in $R$. solanacearum GMI1000 (Salanoubat et al. 2002). On the GMI1000 Web site, RS04833 is annotated as being AvrA because we provided French scientists the DNA sequence of AW1 avrA prior to this report. Surprisingly, alignment of the amino acid sequences for AvrA from AW1 and GMI1000, revealed that they are only $60 \%$ identical, mostly because the latter protein has 33 fewer residues (Fig. 1B). In comparison, the putative proteins encoded by ORFs downstream of avrA in both strains are 93\% identical (and exactly the same size); ORF04832 in GMI1000 is annotated as a putative lipoprotein gene.

The size of avrA correlates with HR-inducing activity.

A collection of $R$. solanacearum strains isolated from soil and from wilted tomato or tobacco plants in the southeastern United States was screened for the presence of $a v r A$ and the ability to induce the HR in tobacco (Table 1). PCR amplification of $a v r A$ from each of the 139 strains generated either an $\approx 800$-bp DNA fragment, corresponding to the wild-type allele in AW1, or an $\approx 960$-bp fragment. The $\approx 960$-bp allele was present in strains from $96 \%$ of the North Carolina sites and $75 \%$ of the South Carolina sites, but in only $13 \%$ of the sites in Georgia and none of the sites in Florida. All of the tomato strains, except for K60 from North Carolina, contained the wild-type allele. All of the strains from tobacco in Georgia also contained the wild-type allele, but almost all of the strains from tobacco in North and South Carolina contained the $\approx 960$ bp allele. Of the 100 strains of $R$. solanacearum isolated from soil, only 7 contained the wild-type allele.

When infiltrated into tobacco leaves, all the strains in the collection that elicited an HR within 16 to $24 \mathrm{~h}$ after inoculation contained the wild-type allele. In contrast, all of the HRnegative strains (necrosis in 48 to $96 \mathrm{~h}$ ) contained the $\approx 960$-bp allele of avrA. Pathogenicity assays on tobacco and tomato were performed using a selection of strains from tomato, tobacco, and soil to determine whether there was a correlation between HR and pathogenicity. In all cases, the HR-positive strains were pathogenic on tomato but avirulent on tobacco, whereas all HR-negative strains wilted both tomato and tobacco.

\section{AvrA alleles from HR-negative strains contain one of two insertion sequences.}

The $\approx 960$-bp fragments with the avrA alleles from six HRnegative strains (SC06, SC111, NC116, GA102, GA122, and GA142) (Table 2) were cloned, sequenced, and compared with the wild-type, HR-inducing avrA allele from AW1. Nucleotide homology ranged from 95.3 to $99.3 \%$ (and amino acid homology from 84.4 to $97.9 \%$ ) except in regions containing one of two insertions (Figs. 2 and 3). A 155-bp DNA insertion was found in strain GA102 between what would be nucleotides 542 and 543 in wild-type avrA (counting from the ATG start codon). This insertion has a low $\mathrm{G}+\mathrm{C}$ content of $54.5 \%$, a 16 bp imperfect terminal inverted repeat, and a 3-bp direct repeat of the insertion site in $a v r A$ (Figs. 2B and 3A). The 152-bp

Table 1. Summary of Ralstonia solanacearum strains used in this study

\begin{tabular}{|c|c|c|c|c|c|c|c|c|}
\hline \multirow[b]{2}{*}{ State } & \multicolumn{4}{|c|}{ No. of strains from } & \multicolumn{2}{|c|}{ No. of strains containing $a v r A$} & \multirow[b]{2}{*}{ No. of sites } & \multirow[b]{2}{*}{ No. sites containing 972-bp avrA } \\
\hline & Tobacco & Tomato & Soil & Total & 792-bp & 972-bp & & \\
\hline $\mathrm{NC}$ & 2 & 1 & 37 & 40 & 1 & 39 & 24 & 23 \\
\hline $\mathrm{SC}$ & 11 & 4 & 19 & 34 & 10 & 24 & 20 & 15 \\
\hline GA & 3 & 10 & 42 & 55 & 16 & $39^{z}$ & 25 & 3 \\
\hline FL & 0 & 12 & 0 & 12 & 12 & 0 & 9 & 0 \\
\hline
\end{tabular}

${ }^{\mathrm{z}}$ Of these strains, 34 were from soil from the same field with a history of bacterial wilt of tobacco.

Table 2. Partial list of Ralstonia solanacearum strains used in the study with their hypersensitivity reaction on tobacco and DNA fragment size of the polymerase chain reaction amplified avrA gene ${ }^{\mathrm{t}}$

\begin{tabular}{|c|c|c|c|c|c|c|c|}
\hline Isolate & State & Host & $\begin{array}{c}\text { Size of } a v r \text { A gene } \\
\text { (bp) }\end{array}$ & $\begin{array}{c}\text { Nucleotide } \\
\text { homology }(\%)^{u}\end{array}$ & $\begin{array}{c}\text { Amino acid } \\
\text { identity }(\%)^{\mathrm{v}}\end{array}$ & $\begin{array}{l}\text { HR on } \\
\text { tobacco }\end{array}$ & Source $^{w}$ \\
\hline SC06 & $\mathrm{SC}$ & Tobacco & 972 & 98.9 & $97.7^{x}$ & - & Robertson et al. 2001 \\
\hline SC14 & SC & Tomato & 792 & ND & ND & + & This study \\
\hline $\mathrm{SC} 17-1^{\mathrm{y}}$ & $\mathrm{SC}$ & Tobacco & 792 & 97.9 & 94.9 & + & This study \\
\hline $\mathrm{SC} 17-1 \mathrm{M}^{\mathrm{z}}$ & $\ldots$ & $\ldots$ & $\approx 2,800$ & $\ldots$ & $\ldots$ & $\ldots$ & This study \\
\hline SC108 & $\mathrm{SC}$ & Soil & 972 & ND & ND & - & This study \\
\hline SC111 & $\mathrm{SC}$ & Soil & 972 & 99.1 & 97.9 & - & This study \\
\hline 342 & $\mathrm{NC}$ & Tobacco & 972 & ND & ND & - & T. Denny, UGA \\
\hline K60 & $\mathrm{NC}$ & Tomato & 972 & ND & ND & - & Robertson et al. 2001 \\
\hline $\mathrm{NC} 116$ & $\mathrm{NC}$ & Soil & 972 & 97.8 & 95.3 & - & This study \\
\hline NC136 & $\mathrm{NC}$ & Soil & 972 & ND & ND & - & This study \\
\hline $108-3$ & GA & Tobacco & 792 & ND & ND & + & T. Denny, UGA \\
\hline AW1 & GA & Tomato & 792 & 100 & 100 & + & Carney and Denny 1990 \\
\hline GA102 & GA & Soil & 947 & 99.3 & 84.4 & - & This study \\
\hline GA122 & GA & Soil & 972 & 98.5 & 95.1 & - & This study \\
\hline GA142 & GA & Soil & 972 & 98.6 & 95.1 & - & This study \\
\hline RS14 & FL & Tomato & 792 & ND & ND & + & T. Momol, UFL \\
\hline RS19 & FL & Tomato & 792 & ND & ND & + & T. Momol, UFL \\
\hline
\end{tabular}

${ }^{\mathrm{t}}$ Representative strains were chosen for each state and each $a v r A$ allele. States: NC $=$ North Carolina, SC $=$ South Carolina, and GA = Georgia; HR = hypersensitive response; $\mathrm{ND}=$ not done.

" Nucleotide homology to $a v r A$ in AW1 (\%) excluding inserted DNA.

${ }^{v}$ Amino acid identity with $a v r A$ in AW1 (\%) excluding inserted DNA.

${ }^{\mathrm{w}}$ Name of donor, affiliation (UFL = University of Florida; UGA = University of Georgia).

${ }^{\mathrm{x}}$ Homology of the first 43 amino acids. A single base insertion between nucleotides 132/133 results in a reading frame shift.

${ }^{y}$ Nalidixic acid resistant mutant of SC17.

${ }^{\mathrm{z}}$ avrA knockout strain. 
sequence resembles a miniature inverted-repeat transposable element (MITE) (Brugger et al. 2002), and has two divergent ORFs that are 144 and 141-bp long; however, neither has any known coding potential. This putative MITE is not homologous to any sequence in the GenBank database. We searched for known insertion sequence (IS) elements that are related to the 152-bp MITE at the IS Finder Web site and found that the left and right ends (Fig. 3) are 93.8 and 100\%, respectively, identical to the 18-bp imperfect terminal inverted repeat in ISRso1 (GenBank AF239240) (Poussier et al. 2003) Little sequence similarity was detected between the central regions of the 152-bp MITE and ISRso1. The 3-bp direct repeat, TTA, was identical to the direct repeat reported for one mobile copy of ISRso1 in strain GMI1000 (Poussier et al. 2003). Insertion of the 152-bp MITE creates a stop codon at the insertion point (Fig. 3A), which results in a severely truncated AvrA protein.

In the remaining five strains, a 180-bp insertion was found between nucleotides 574 and 575 in SC111, and between nucleotides 461 and 462 in SC06, NC116, GA122, and GA142. The insertion is in the inverse orientation in SC06 compared with the other four strains. This larger insertion has an even lower $\mathrm{G}+\mathrm{C}$ content of 52.2\%, a putative 170-bp MITE with a 13-bp inverted terminal repeat, a 10-bp direct repeat of the insertion site in avrA (Figs. 2C and 3B), and two ORFs, 138 and 133 bp long, with no coding capacity, in the same orientation but different reading frames. No IS elements related to the 170-bp MITE were found using the IS Finder Web site. A BLASTn search of the GenBank database using the putative 170-bp MITE as the query revealed that the only significant homology ( $>99 \%$ ) is to a 170-bp sequence within the 722-bp intergenic region upstream of phcA in $R$. solanacearum AW1
(Brumbley and Denny 1993). Each insertion of the 170-bp MITE would result in altered or truncated avrA proteins (Fig. 3B). The avrA allele in strain SC06 also contained a single base insertion between nucleotides 132 and 133 which resulted in a reading frame shift. Therefore, the presence of the

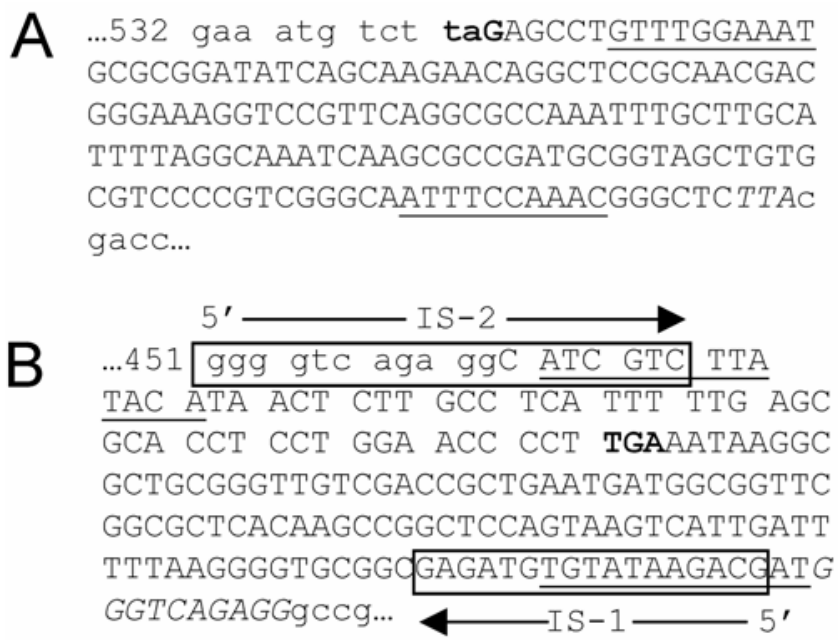

Fig. 3. Miniature inverted-repeat transposable element (MITE) DNA A, 152 $\mathrm{bp}$ and $\mathbf{B}, 170$-bp sequences showing the terminal inverted repeats and direct repeats. The nucleotide sequences of the insertion elements are shown in upper case, the inverted repeats are underlined, and the direct repeats are italicized. The primer sites for IS- 1 and IS- 2 are outlined and their $5^{\prime}$ to $3^{\prime}$ orientation is shown. The stop codon created by insertion of each MITE is in bold. Only one insertion site of the 170-bp MITE is shown.
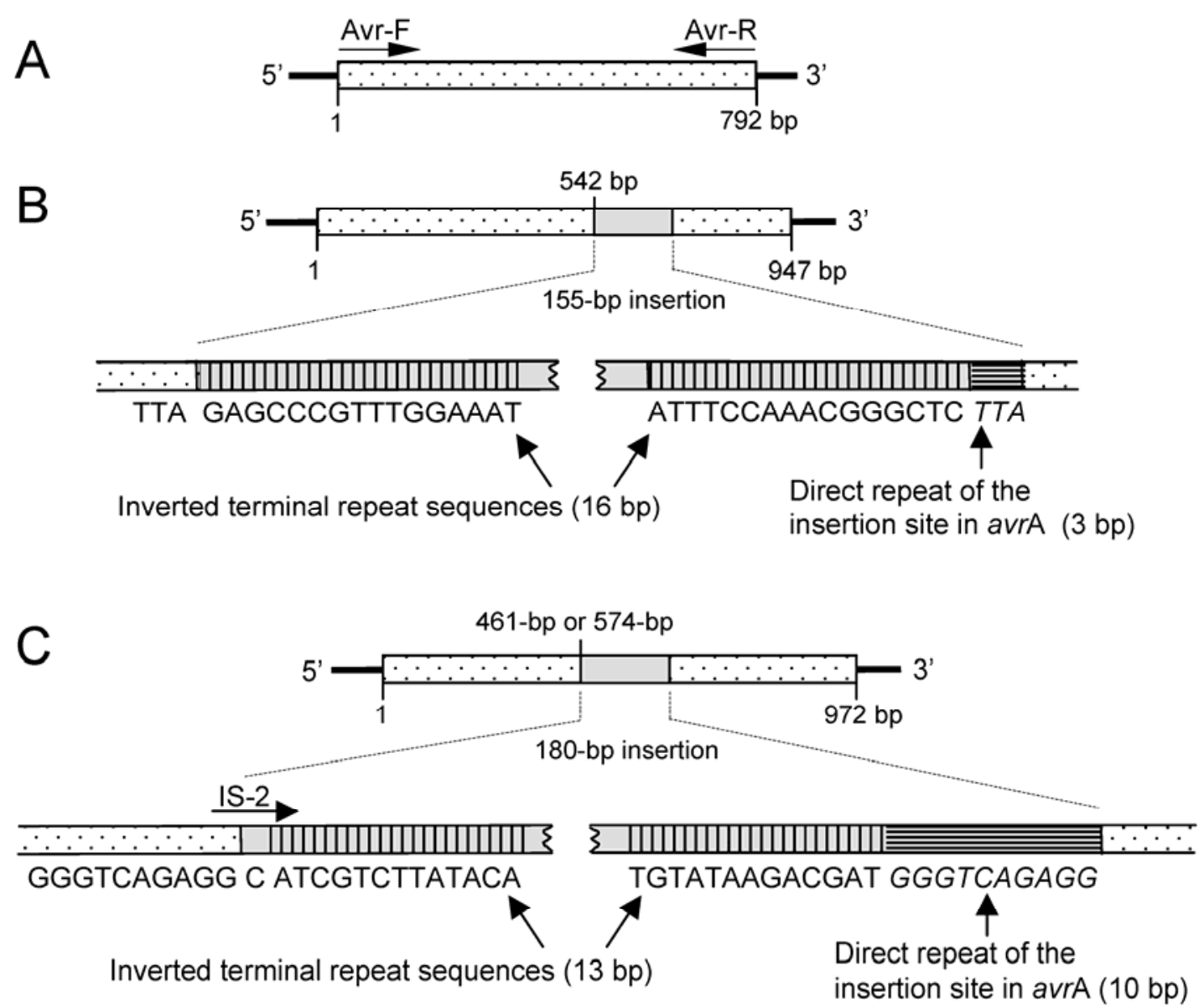

Fig. 2. Diagram showing A, wild-type avrA allele, B, 155-bp insertion in avrA in GA102 that results in the 947-bp allele, and C, 180-bp insertion in strains such as SC06, SC111, NC116, GA122, and GA142 that results in the 972-bp allele. 
170-bp MITE in this allele may be meaningless, because the wild-type protein already is destroyed (Brumbley and Denny 1993). Multiplex PCR with primers Avr-F, Avr-R, and IS-2 was used to screen all HR-negative strains for the presence of the 170-bp MITE. Because IS-2 hybridizes to the junction between the MITE and the duplicated avrA sequence (Fig. 2C), PCR amplification generates 972- and a 518-bp products corresponding to avrA and the MITE plus the $3^{\prime}$ end of avrA, respectively (Fig. 4), only when the MITE is present between nucleotides 461 and 462. The 170-bp MITE was present in avrA in all of the North Carolina strains, all Georgia strains except GA102, and in all but five of the South Carolina strains (Fig. 4). Sequence analysis of avrA in one of these five strains, SC111, showed the 170-bp MITE to be present in the gene, but at a different insertion site; that is, between nucleotides 574 and 575 .

\section{R. solanacearum strains from the southeastern United States carry multiple copies of the 179-bp MITE.}

A PCR fragment containing the 170-bp MITE was used to probe EcoRI-digested genomic DNA from $14 R$. solanacearum strains from the Carolinas, Georgia, and Florida. All the strains were found to contain a copy of this MITE on at least 10 restriction fragments (Fig. 5). The variation in signal intensity could be due to different numbers of the MITE on the different fragments or due to differences in homology. The results also showed that strains K60 and 342 have very similar restriction fragment length polymorphism fingerprints, but that the other 12 strains are unique (Fig. 5).

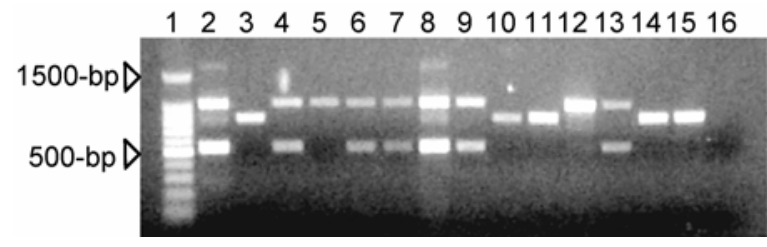

Fig. 4. Polymerase chain reaction (PCR) amplification, using the primers AvrA-F, AvrA-R, and IS-2 of the avrA gene in selected Ralstonia Solanacearum strains from North Carolina, South Carolina, Georgia, and Florida. Lane $1=100$-bp marker, lane $2=$ SC06, lane $3=$ SC14, lane $4=$ SC108, lane $5=$ SC111, lane $6=342$, lane $7=\mathrm{K} 60$, lane $8=\mathrm{NC} 116$, lane $9=\mathrm{NC} 136$, lane $10=108-3$, lane $11=\mathrm{AW} 1$, lane $12=\mathrm{GA} 102$, lane $13=\mathrm{GA} 122$, lane $14=$ RS14, lane $15=$ RS19, and lane $16=$ PCR negative control

Table 3. Hypersensitivity reaction on tobacco and the area under disease progress curve (AUDPC) on tobacco and tomato of the transconjugants and their respective parents

\begin{tabular}{lcccc}
\hline & & & \multicolumn{2}{c}{ AUDPC $^{\mathbf{x}}$} \\
\cline { 4 - 5 } Strain $^{\mathbf{y}}$ & avrA size (bp) & HR $^{\mathbf{z}}$ & Tobacco & Tomato \\
\hline AW1 & 792 & + & $0.00 \mathrm{~d}$ & $63.13 \mathrm{a}$ \\
SC06-1 & 972 & - & $52.63 \mathrm{ab}$ & $52.25 \mathrm{ab}$ \\
SC06-1(pRK404) & 972 & - & $32.63 \mathrm{c}$ & $59.25 \mathrm{a}$ \\
SC06-1(pBC738) & $972 / 792$ & + & $3.13 \mathrm{~d}$ & $0.38 \mathrm{~d}$ \\
K60-1 & 972 & - & $32.63 \mathrm{c}$ & $48.75 \mathrm{abc}$ \\
K60-1(pRK404) & 972 & - & $35.5 \mathrm{bc}$ & $27.5 \mathrm{bcd}$ \\
K60-1(pBC738) & $972 / 792$ & + & $0.00 \mathrm{~d}$ & $23.75 \mathrm{~cd}$ \\
NC116-1 & 972 & - & $32.63 \mathrm{c}$ & $55.25 \mathrm{a}$ \\
NC116-1(pRK404) & 972 & - & $51.25 \mathrm{abc}$ & $36.63 \mathrm{abc}$ \\
NC116-1(pBC738) & $972 / 792$ & + & $1.75 \mathrm{~d}$ & $4.38 \mathrm{~d}$ \\
GA102-1 & 947 & - & $57.38 \mathrm{a}$ & $62.88 \mathrm{a}$ \\
GA102-1(pRK404) & 947 & - & $32.63 \mathrm{bc}$ & $62.25 \mathrm{a}$ \\
GA102-1(pBC738) & $947 / 792$ & + & $0.00 \mathrm{~d}$ & $7.38 \mathrm{~d}$ \\
\hline
\end{tabular}

${ }^{x}$ AUDPC was based on the measurement of the wilt index over time. Means within columns followed by different letters are significantly different by Fisher's protected least significant difference $(P<0.05)$.

${ }^{\mathrm{y}}$ pRK404 = empty vector; $\mathrm{pBC738}=\mathrm{pRK} 404:$ :avrA.

${ }^{\mathrm{z}}$ Hypersensitive response (HR) elicited (+) or not elicited (-) within $16 \mathrm{~h}$.
The wild-type avrA allele reduces virulence on both tobacco and tomato.

The HR and pathogenicity on tobacco and tomato of four HR-negative $R$. solanacearum strains before and after the introduction of wild-type $a v r$ A on a plasmid was assessed. As expected based on the results of Carney and Denny (1990), introduction of $\mathrm{pBC} 738$ endowed the transconjugants with the ability to elicit an HR when infiltrated into tobacco leaves and virtually eliminated pathogenicity when inoculated on tobacco roots (Table 3). Thus, the wild-type $a v r$ A allele is dominant to the mutated alleles. Unexpectedly, the presence of multiple copies of wild-type avrA in trans (5 to 10 copies/cell) resulted in a significant reduction of pathogenicity on tomato (Table 3 ). This suggests that overproduction of AvrA interferes with normal pathogenic processes or triggers a resistance response in normally susceptible tomato.

\section{avrA does not contribute to pathogenicity on tomato.}

The HR and pathogenicity on tobacco and tomato of the avrA mutant, SC17-1M was compared with its parent, SC17-1, to determine the role of its effector protein on these traits. Unlike its parent strain, SC17-1M was HR negative and weakly pathogenic on tobacco. Thus, as was observed earlier for the avrA mutant strain AW1-31 (Carney and Denny 1990), inactivation of $a v r A$ in SC17-1 did not make it as pathogenic as a natural tobacco-pathogenic strain (e.g., SC06). When tested on tomato, there was no statistical difference in the pathogenicity of the four strains $(\mathrm{P}=0.2230)$, even though SC17-1M was somewhat more aggressive than its wild-type parent (Table 4). Therefore, avrA did not contribute to the ability of SC17-1 to cause disease on tomato.

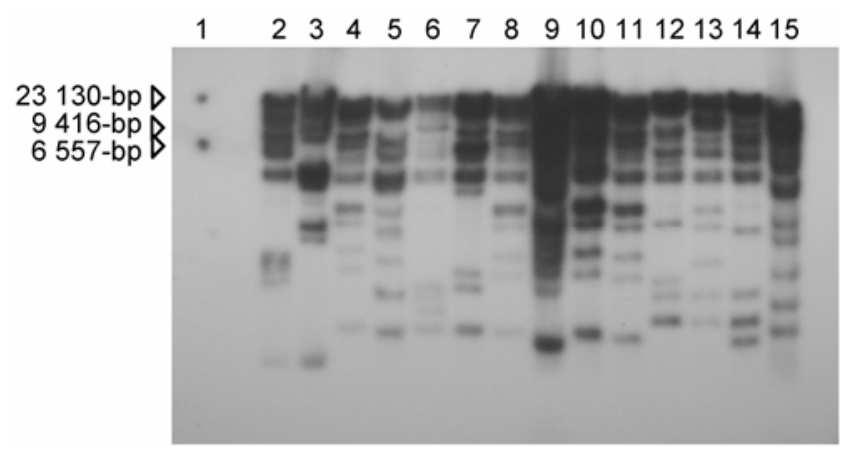

Fig. 5. Southern blot analysis of EcoRI-digested genomic DNA from 14 Ralstonia solanacearum strains probed with the 170-bp miniature inverted-repeat transposable element. Lane $1=$ Lambda DNA/HindIII marker, lane $2=\mathrm{RS} 19$, lane $3=\mathrm{RS} 14$, lane $4=\mathrm{GA} 122$, lane $5=\mathrm{GA} 102$, lane $6=\mathrm{AW} 1$, lane $7=108-3$, lane $8=\mathrm{NC} 136$, lane $9=\mathrm{NC} 116$, lane $10=$ $\mathrm{K} 60$, lane $11=342$, lane $12=\mathrm{SC} 111$, lane $13=\mathrm{SC} 108$, lane $14=\mathrm{SC} 14$, and lane $15=\mathrm{SC} 06$

Table 4. Hypersensitivity reaction on tobacco and the area under disease progress curve (AUDPC) on tobacco and tomato of Ralstonia solanacearum SC17-1 and the avrA knockout mutant, SC17-1M

\begin{tabular}{lcccc}
\hline & & & \multicolumn{2}{c}{ AUDPC $^{\mathbf{x}}$} \\
\cline { 5 - 6 } Strain & $\boldsymbol{a v r A ~ s i z e ~ ( b p ) ~}$ & $\mathbf{H R}^{\mathbf{y}}$ & Tobacco & Tomato $^{\mathbf{z}}$ \\
\hline AW1 (control) & 792 & + & $0.0 \mathrm{c}$ & 57.38 \\
SC06 (control) & 972 & - & $52.65 \mathrm{a}$ & 52.25 \\
SC17-1 & 792 & + & $0.0 \mathrm{c}$ & 31.25 \\
SC17-1M & 2,800 & - & $16.0 \mathrm{~b}$ & 59.13 \\
\hline
\end{tabular}

${ }^{x}$ AUDPC was based on the measurement of disease severity over time. Means within columns followed by different letters are significantly different by Fisher's protected least significant difference $(P<0.05)$.

${ }^{y}$ Hypersensitive response (HR) elicited (+) or not elicited (-) within $16 \mathrm{~h}$.

${ }^{\mathrm{z}}$ Analysis of variance of the AUDPC data was not significant $(P=0.2230)$. 


\section{DISCUSSION}

Millions of dollars are lost each year due to bacterial wilt in North and South Carolina. In Georgia and Florida, bacterial wilt rarely is reported on tobacco although it is commonly found on tomato. This difference has been investigated since the early 1950s (Kelman 1953; Kelman and Person 1961). We investigated how diversity of the avrA gene in $R$. solanacearum populations relates to the observed incidence of bacterial wilt in the southeastern United States. PCR amplification of avrA from 139 strains of $R$. solanacearum from this area generated either 792-bp (wild-type) or $\approx 960$ bp DNA fragments. The modified avirulence gene was present in strains from the majority of the sites sampled in the Carolinas; however, it rarely was found in the sites sampled in Georgia and was not found in Florida. We interpret these data to indicate that the incidence of bacterial wilt of tobacco in this region is explained partially by which $a v r$ A allele occurs more frequently in the local $R$. solanacearum population.

$R$. solanacearum strains that contained the wild-type avrA allele (792 bp) elicited an HR (HR-positive) on tobacco that was light brown and necrotic and appeared 16 to $24 \mathrm{~h}$ after inoculation. All HR-negative strains contained the modified allele $(\approx 960-b p)$ and caused chlorosis of the infiltrated tissue 36 to $72 \mathrm{~h}$ after inoculation, followed by necrosis 48 to $96 \mathrm{~h}$ post inoculation. We found all of the HR-positive strains to be pathogenic on tomato and avirulent on tobacco. In contrast, Prior and Steva (1990) reported that $R$. solanacearum strains from the French West Indies were both pathogenic and induced HR on tobacco. We believe this observation resulted from the method of inoculation used. The phenotype we report (i.e., HR positive and pathogenic negative) was obtained using the root-drenching method of inoculation in the pathogenicity bioassay. However, if we used stem inoculation, as reported by Prior and Steva (1990), all of our HRpositive strains also wilted tobacco (wilt indices ranged from $2 / 5$ to $5 / 5)$.

Cloning and sequencing of the avrA gene from six of the HR-negative strains revealed the presence of one of two DNA insertion sequences, 170 or $152 \mathrm{bp}$ in length. Both of these DNA fragments possess features similar to MITEs (Brugger et al. 2002). They are small $(<500 \mathrm{bp})$, bound by terminal inverted repeats (TIRs), 13 and $16 \mathrm{bp}$, respectively, and are flanked by a target site duplication (TSD), 10 and $3 \mathrm{bp}$, respectively, of the avrA gene. They also do not code for any functional protein. MITE-like elements have been reported in a few other prokaryotes, namely, RUP (repeat unit of pneumococcus) elements in Streptococcus spp. (Oggioni and Claverys 1999), Neisseria miniature insertion sequences (nemis) in Neisseria spp. (Mazzone et al 2001), and an unnamed element in Photorhabdus luminescans (Mahillon et al. 1999).

Sequence similarities exist between some MITEs and class II elements. This implies that a MITE could be mobilized by transposase activity encoded by the analogous class II element (Buisine and Tang 2002; Feschott and Mouches 2000; Oggioni and Claverys 1999; Redder et al. 2001). Using the "bottom-up approach" (Feschotte et al. 2002), we identified the likely partner transposase, ISRso1, of the 152-bp MITE. ISRso1 belongs to the IS5 family and also duplicates the trinucleotide TTA upon insertion into phcA in R. solanacearum strain GMI1000 (Poussier et al 2003). This TSD indicates that the 152-bp MITE is a Tourist-like MITE and that ISRso1 belongs to the superfamily of transposase Tc1/Mariner (Feschotte and Mouches 2000; Jiang et al. 2003). It is possible that the 152-bp MITE was derived from ISRso1. The Emigrant family of MITEs, in Arabidopsis, arose from Lemi1, which encodes a putative transposase (Feschotte and Mouches 2000).
Although we found no IS related to the 170-bp MITE, sequence analysis revealed that AW1 has this MITE upstream of phcA, and Southern analysis (Fig. 5) showed that many additional copies of this MITE are present in this and other strains from the southern United States. Brumbley and Denny (1993) similarly noted the presence of a repeated sequence in some $R$. solanacearum strains when they probed a Southern blot of genomic DNAs using a labeled fragment containing $p h c A$ and its upstream region (i.e., including the 170-bp MITE). It is significant that, in the same experiment, they did not detect a repeated sequence in strains from around the globe classified as race 1/biovars 3 or 4 (GMI1000, UW130, and UW143), race 2/biovar 1 (UW9, UW20, and UW127), and race 3/biovar2 (UW19, UW23, and UW150). Furthermore, the 170bp MITE is not present in the GMI1000 genomic sequence. Thus, it is possible that the 170-bp MITE is unique to $R$. solanacearum strains from the southeastern United States and Caribbean basin. Likewise, it is possible that an IS encoding the transposase for mobilizing the 170-bp MITE might be unique to this population. In $P$. luminescans, a MITE-like element was found to have homology to a new IS found as an intact copy in the $P$. luminescans genome (Mahillon et al. 1999).

Mobile genetic elements play an important role in generating genetic diversity by facilitating gene loss or acquisition and genomic rearrangement via homologous recombination (Mahillon and Chandler 1998). Strains that contain insertion sequences in identical positions are likely to be closely related (Mahillon and Chandler 1998). Multiplex PCR of avrA in all the southeastern $R$. solanacearum strains containing the 972 bp allele revealed that the 170-bp DNA insertion was inserted between nucleotides 461 and 462 in the avrA gene in 89 of the 94 strains tested. In five of the South Carolina strains, the 518bp DNA fragment was not amplified, implying that either this element was not present in these strains, or it was located at a different site in the gene. These five strains were collected from two fields in Williamsburg County. Cloning and sequencing $a v r A$ from one of the five strains that did not amplify the 518-bp DNA fragment, SC111, found the 170-bp MITE to be present and located between nucleotides 574 and 575. Therefore, the strains examined probably are closely related, but they are not strictly clonal because the MITEs are present on different-sized restriction fragments.

This is not the first report of a DNA insertion in an avr gene resulting in virulence on a resistant host. An insertion of 104 bp in the avrPphE allele in Pseudomonas syringae pv. phaseolicola race 8 was found to be one of the two routes to virulence of this pathogen (Stevens et al. 1998). Similarly, a 1.2-kb insertion sequence, IS476, in the $a v r B s_{1}$ locus in spontaneous mutants of $X$. campestris pv. vesicatoria Race 2 (Kearney et al. 1988) was shown to result in a race shift and, consequently, pathogenicity on resistant cultivars of field-grown pepper (Kousik and Ritchie 1996). However, this is, to our knowledge, the first report showing a relationship between geographic origin of isolation and the presence of IS elements at a specific genetic locus.

It has been demonstrated that $a v r$ genes may be involved in phenotypes other than mediating gene-for-gene interactions with plant disease resistance genes. For example, Jackson and associates (1999) showed virPphA in P. syringae pv. phaseolicola was a virulence determinant on bean but acted as an $a v r$ gene in soybean. The genetic insertions in the avrA locus allow $R$. solanacearum to evade the recognition and defense response of tobacco; therefore, it is possible that avrA acts in a similar fashion; that is, as a virulence determinant on susceptible hosts and an avirulence determinant on tobacco. Quantitative losses of virulence have been observed for insertion mutants of several $P$. syringae avr genes, leading to the suggestion that 
most pathogens carry an array of factors that contribute to virulence (Lorang et al. 1994) in addition to triggering plant disease resistance genes (Dangl and Holub 1997). For example, the avirulence gene avrBs2, which is highly conserved among strains of $X$. campestris, is needed for full virulence of the pathogen on susceptible hosts (Kearney and Staskawicz 1990b). Nevertheless, our results suggest that avrA is not a virulence determinant on tomato because strains containing the 972-bp allele were not significantly less virulent on tomato than strains containing the wild-type allele when tested under controlled environmental conditions.

Some bacterial $a v r$ genes increase virulence only when present in the appropriate species, strain, or pathovar or a pathovar on a particular host species or variety (White et al. 2000). For example, the virulence effects of avrA and $a v r E$ have been observed only in $P$. syringae pv. tomato strain PT23 (Lorang et al. 1994; White et al. 2000). AvrRpt2 of P. syringae pv. tomato DC3000 has a virulence effect on No-0 land race of Arabidopsis but not on land race Col-0 (White et al. 2000). $R$. solanacearum has a wide host range; therefore,, it is possible that $a v r A$ may be a virulence factor on another host plant species. A number of the strains used in this study were isolated from soil from a Georgia field planted to green pepper with a history of bacterial wilt on tomato. All of the strains that contained the modified avrA allele were very aggressive on tobacco under controlled environment conditions; however, no wilt symptoms were observed on pepper in the field. It remains to be determined whether either a second avirulence gene is involved in the pepper- $R$. solanacearum interaction or whether the insertion in $a v r \mathrm{~A}$ results in a loss of virulence on pepper.

Investigations into the avirulence loci of $R$. solanacearum may aid in our understanding of both the host range and survival exhibited by this diverse pathogen. This will have significant implications for the development of novel control strategies for this aggressive pathogen with a worldwide distribution.

\section{MATERIALS AND METHODS}

Bacterial strains, plasmids, media, and culture conditions.

Five plasmids were used: pGEM-T Easy (Promega Corp., Madison, WI, U.S.A.), pBC738 (avrA, Tc ${ }^{\mathrm{r}}$ ) (Carney and Denny 1990), pRK2013 (Ditta et al. 1980), pRK404 (Ditta et. al. 1985), and pBluescript II (Stratagene, La Jolla, CA, U.S.A.). $R$. solanacearum strains were grown routinely on either CPG or TTC media (Denny and Hayward 2001) or in $1 / 10$ BG broth at $28^{\circ} \mathrm{C}$ (Carney and Denny 1990). Spontaneous nalidixic acid-resistant $R$. solanacearum strains SC06-1, SC17-1, NC116-1, GA102-1, and NC25-1 were selected by plating $>10^{9}$ cells on CPG plates containing the antibiotic at $100 \mu \mathrm{g}$ $\mathrm{ml}^{-1}$. Media used for the selection of transconjugants were supplemented with the following antibiotics: nalidixic acid at $100 \mu \mathrm{g} \mathrm{ml}^{-1}$ and tetracycline at $15 \mu \mathrm{g} \mathrm{ml}^{-1}$. Escherichia coli was cultured at $37^{\circ} \mathrm{C}$ in Luria-Bertani (LB) broth (Sambrook et al. 1989). E. coli transformants were plated on LB agar plates containing ampicillin at $50 \mu \mathrm{g} \mathrm{ml}^{-1}$, 5-bromo-4-chloro3-indolyl-beta-D-galactopyranoside (X-Gal) at $40 \mu \mathrm{g} \mathrm{ml}^{-1}$, and $40 \mu \mathrm{M}$ isopropyl-beta-D-thiogalactopyranoside (IPTG).

\section{Plant assays.}

Inoculum from each of the $R$. solanacearum strains was prepared as previously described from a stock culture that had been maintained in sterile distilled water at room temperature $\left(\approx 25^{\circ} \mathrm{C}\right)$ (Robertson et al., 2001). Typical fluidal colonies of 48-h cultures grown on TTC medium were used to inoculate $50 \mathrm{ml}$ of $1 / 10 \mathrm{BG}$ broth. The cultures were grown overnight at $28^{\circ} \mathrm{C}$ with constant shaking $(200 \mathrm{rpm})$. The broth cultures were pelleted at $10,000 \times g$ for $10 \mathrm{~min}$ and the pellet suspended in sterile distilled water. Bacterial cell density was determined spectrophotometrically and adjusted to an optical density at $600 \mathrm{~nm}\left(\mathrm{OD}_{600}\right)=0.2\left(\approx 10^{8} \mathrm{CFU} \mathrm{ml} \mathrm{Cl}^{-1}\right)$.

For HR assays, $R$. solanacearum inoculum was infiltrated into the intercellular spaces of fully expanded tobacco leaves (Nicotiana tabacum, 'K326') (Carney and Denny 1990). Inoculated plants were placed in a controlled environment chamber at $30^{\circ} \mathrm{C}$ with a 12 -h photoperiod. Four inoculations on two plants were performed for each isolate. Plant reactions were scored daily for up to 4 days after inoculation.

Pathogenicity of $R$. solanacearum strains on the tomato ( $L y$ copersicon esculentum 'Marion') and the tobacco K326 was assessed as described previously (Robertson et al. 2001). Briefly, 6-week-old tobacco seedlings, with four to six leaves, were transplanted into individual 3-in. pots and inoculated $24 \mathrm{~h}$ later by drenching the soil with $20 \mathrm{ml}$ of inoculum $\left(\mathrm{OD}_{600}=\right.$ 0.2 ). Each pot was placed on a petri dish to avoid cross contamination. Five replications in a complete randomized block design were used and the experiment was repeated three times. Wilting was assessed every 3 days from 7 days after inoculation for a total of 21 days using the following scale (Robertson et al. 2001): $0=$ healthy, $1=$ one leaf wilted, $2=$ two leaves wilted, $3=$ three leaves wilted, $4=$ whole plant wilted, and $5=$ plant dead. Disease progress curves were constructed from the wilt index data, and the area under the disease progress curve (AUDPC) was calculated for each strain using the method of Shaner and Finney (1977). The AUDPC was subjected to analysis of variance (ANOVA; SAS Institute, Cary, NC, U.S.A.), and Fisher's protected least significant difference (LSD) was calculated for all $F$ values that indicated significance $(P<0.05)$.

\section{General DNA procedures.}

Genomic DNA was prepared using the proteinase K-sarcosyl lysis miniprep of Boucher and associates (1987) and was quantified using a Biophotometer (Brinkman Instruments, Inc., Westbury, NY, U.S.A.). Plasmid DNA isolations were performed using Qiagen kits (Qiagen Inc., Chatsworth, CA, U.S.A.). Southern blotting and hybridization were done using standard techniques (Sambrook et al. 1989). For each isolate, 5 $\mu \mathrm{g}$ of genomic DNA was restricted with EcoRI, resolved on a $1 \%$ agarose gel, and transferred to a positively charged nylon membrane. The 170-bp MITE was amplified and the PCR product gel purified using the Geneclean spin kit (Bio101, Vista, CA, U.S.A.) and then labeled using $\left[\alpha^{32} \mathrm{P}\right]-\mathrm{dCTP}$ and the Multiprime labeling system (Promega Corp.). The probe was hybridized overnight at $65^{\circ} \mathrm{C}$, washed at $65^{\circ} \mathrm{C}$ in $2 \times \mathrm{SSC}$ ( $1 \times \mathrm{SSC}$ is $0.15 \mathrm{M} \mathrm{NaCl}$ plus $0.015 \mathrm{M}$ sodium citrate) and $0.5 \%$ sodium dodecyl sulfate, and exposed to autoradiographic $\mathrm{X}$-ray film.

\section{PCR amplification, cloning, and DNA sequencing.}

Primers, synthesized by Life Technologies (Rockville, MD, U.S.A.), were designed to the $5^{\prime}$ and $3^{\prime}$ end of the avrA gene (Avr-F: 5'-CAAGATGAGAAGAATTGGAAAAC and Avr-R: 5'-CTCGCTGTCGCTATCGTTGCC; the AvrA start codon is underlined), and to both ends of the 170-bp MITE (IS-1: 5'CGTCTTATACACATCTC and IS-2: 5'-GGGTCAGAGGCAT CGTC). Each 25- $\mu$ l PCR reaction consisted of: $1.5 \mathrm{mM}$ $\mathrm{MgCl}_{2}, 400 \mu \mathrm{M}$ dNTPs, primers at 50 and 100 pmol for $a v r \mathrm{~A}$ and MITE primer sets, respectively, 1.0 unit of Taq DNA polymerase (Promega Corp.) and $25 \mathrm{ng}$ of genomic DNA. The thermocycler conditions using the avrA primer set were $3 \mathrm{~min}$ of denaturation at $94^{\circ} \mathrm{C}$; followed by 30 cycles of $94^{\circ} \mathrm{C}$ for 1 min, $60^{\circ} \mathrm{C}$ for $1.5 \mathrm{~min}$, and $72^{\circ} \mathrm{C}$ for $1 \mathrm{~min}$; with a final extension of $10 \mathrm{~min}$ at $72^{\circ} \mathrm{C}$. Cycling conditions for the MITE primer set were $3 \mathrm{~min}$ at $96^{\circ} \mathrm{C}$; followed by 40 cycles of $94^{\circ} \mathrm{C}$ for 30 
$\mathrm{s}, 60^{\circ} \mathrm{C}$ for $30 \mathrm{~s}$, and $72^{\circ} \mathrm{C}$ for $30 \mathrm{~s}$; with a final extension for $10 \mathrm{~min}$ at $72^{\circ} \mathrm{C}$. Multiplex PCR reactions contained $50 \mathrm{pmol}$ each of the primers $a v r A-\mathrm{F}$, $a v r A-\mathrm{R}$, and IS-2, and the other components as above. The cycling conditions were $3 \mathrm{~min}$ at $94^{\circ} \mathrm{C}$; followed by 22 cycles of $94^{\circ} \mathrm{C}$ for $1 \mathrm{~min}, 58^{\circ} \mathrm{C}$ for 1.5 min, and $72^{\circ} \mathrm{C}$ for $1 \mathrm{~min}$; and finally $10 \mathrm{~min}$ at $72^{\circ} \mathrm{C}$. Amplified products were resolved in a $1 \%(\mathrm{wt} / \mathrm{vol})$ agarose gel stained with ethidium bromide and visualized under ultraviolet light.

The original DNA sequence of the 2.3-kb region of the AW1 genome containing avrA in pBC738 was determined as described previously (Carney and Denny 1990). To sequence avrA alleles from other strains, the desired fragments were PCR amplified from genomic DNAs, gel purified using the Geneclean spin kit, ligated into pGEM-T Easy using the manufacturer's protocol (Promega Corp.), and transformed by heat shock into E. coli DH10B. Transconjugants with recombinant plasmids were selected by plating on LB agar containing ampicillin, IPTG, and X-Gal as described above. The DNA sequence of the inserts was determined using a BigDye Terminator Cycle sequencing kit (Applied Biosystems, Foster City, CA, U.S.A.) and an ABI 373A automated DNA sequencer. Analysis of DNA sequence data was performed using GeneJockey (version 1.2; Biosoft, Cambridge, U.K.). Sequence homology searches were performed using BLASTn and BLASTx algorithms through the NCBI (Altschul et al. 1990).

\section{Bacterial conjugations.}

Triparental matings to introduce pBC738 into spontaneous nalidixic-acid resistant strains of $R$. solanacearum were performed as described previously (Carney and Denny 1990) using E. coli containing pRK2013 as the helper strain. Transconjugants were selected on BG plates containing nalidixic acid and tetracycline. The presence of the wild-type $a v r \mathrm{~A}$ gene in each transconjugant was confirmed by PCR amplification as described above.

\section{Site-directed mutagenesis of avrA.}

The Pst I fragment containing avrA from pBC738 was ligated into a derivative of pBluescript SK lacking an EcoRI site to create pAR12 (Amp $\left.{ }^{\mathrm{r}}, a v r A\right)$. Insertion of the streptomycin-spectinomycin $\left(\mathrm{Sp} / \mathrm{Sm}^{\mathrm{r}}\right)$ resistance cassette from a Tn5derived minitransposon (de Lorenzo et al. 1990) into the EcoRI site within $a v r A$ created pAR28 $\left(\mathrm{Amp}^{\mathrm{r}}, a v r A: \mathrm{Sp} / \mathrm{Sm}^{\mathrm{r}}\right)$. The PstI fragment from pAR28 was subcloned into pRK404 $\left(\right.$ Tet $\left.^{r}\right)$ to create pAR31 (Tet ${ }^{\mathrm{r}}$, avrA::Sp/Sm $\left.{ }^{\mathrm{r}}\right)$. Site-directed gene replacement of $a v r A$ was accomplished by transferring pAR31 from $E$. coli $\mathrm{DH} 10 \mathrm{~B}$ into $R$. solanacearum $\mathrm{SC17}-1$. The resultant transconjugants were selected BG plates containing nalidixic acid, tetracycline, and streptomycin. $R$. solanacearum SC17-1M, which had undergone homologous recombination between the plasmid-borne mutant $a v r A$ gene and the wildtype avrA gene, was chosen by screening for $\mathrm{Nal}^{\mathrm{r}} \mathrm{Sp} / \mathrm{Sm}^{\mathrm{r}} \mathrm{Tc}^{\mathrm{r}}$ colonies after passage in broth culture without antibiotics.

\section{LITERATURE CITED}

Abramovitch, R. B., Kim, Y. J., Chen, S., Dickman, M. B., and Martin, G. B. 2003. Pseudomonas type III effector AvrPtoB induces plant disease susceptibility by inhibition of host programmed cell death. EMBO (Eur. Mol. Biol. Organ.) J. 22:60-69.

Altschul, S. F., Gish, W., Miller, W., Myers, E. W., and Lipman, D. J. 1990. Basic local alignment search tool. J. Mol. Biol. 215:403-410.

Altschul, S. F., Madden, T. L., Schäffer, A. A., Zhang, J., Zhang, Z., Webb, M., and Lipman, D. J. 1997. Gapped BLAST and PSI-BLAST: A new generation of protein database search programs. Nucleic Acids Res. 25:3389-3402.

Bogdanove, A. J., Kim, J. F., Wei, Z. M., Kolchinsky, P., Charkowski, A. O., Conlin, A. K., Collmer, A., and Beer, S. V. 1998. Homology and functional similarity of an hrp-linked pathogenicity locus, $d s p E F$, of
Erwinia amylovora and the avirulence locus avrE of Pseudomonas syringae pathovar tomato. Proc. Natl. Acad. Sci. U.S.A. 95:1325-1330.

Boucher, C. A., Vangijsegem, F. Barberis, P. A., Arlat, M., and Zischek, C. 1987. Pseudomonas solanacearum genes controlling both pathogenicity on tomato and hypersensitivity on tobacco are clustered. J. Bacteriol. 169:5626-5632

Brugger, K., Redder, P., She, Q., Confalonieri, F., Zivanovic, Y., and Garrett, R. A. 2002. Mobile elements in archael genomes. FEMS (Fed. Eur. Microbiol. Soc.) Microbiol. Lett. 206:131-141.

Brumbley, S. M., and Denny, T. P. 1993. Cloning of wild-type Pseudomonas solanacearum PhcA, a gene that when mutated alters expression of multiple traits that contribute to virulence. J. Bacteriol. 172:56775685.

Buisine, N., and Tang, C. M. 2002. Transposon-like correira elements: Structure, distribution and genetic exchange between pathogenic Neisseria sp. FEBS (Fed. Eur. Biol. Soc.) Lett. 522:52-58.

Carney, B. F., and Denny, T. P. 1990. A cloned avirulence gene from Pseudomonas solanacearum determines incompatibility on Nicotiana tabacum at the host species level. J. Bacteriol. 172:4836-4843.

Cook, D., Barlow, E., and Sequeira, L. 1989. Genetic diversity of Pseudomonas solanacearum: Detection of restriction fragment length polymerphisms with DNA probes that specify virulence and the hypersensitive response. Mol. Plant-Microbe Interact. 2:113-121.

Cunnac, S., Boucher, C., and Genin, S. 2004. Characterization of the cisacting regulatory element controlling hrpB-mediated activation of the type III secretion system and effector genes in Ralstonia solanacearum. J. Bacteriol. 186:2309-2318.

Dangl, J., and Holub, E. 1997. La dolce vita: A molecular feast in plantpathogen interactions. Cell 91:17-24.

de Lorenzo, V., Herrero, M., Jabkubzik, U., and Timmis, K. 1990. MiniTn5 transposon derivatives for insertion mutagenesis, promoter probing, and chromosomal insertion of cloned DNA in gram-negative eubacteria. J. Bacteriol. 172:6568-6572

Denny, T. P., and Hayward, A. C. 2001. Ralstonia. Pages 151-174 in: Laboratory Guide for Identification of Plant-Pathogenic Bacteria. N. W. Schaad, J. B. Jones, and W. Chun., eds. American Phytopathological Society, St Paul, MN

Ditta, G., Stanfield, S., Corbin, D., and Helinski, D. R. 1980. Broad host range DNA cloning system for gram-negative bacteria: Construction of a gene bank of Rhizobium melilioti. Proc. Natl. Acad. Sci. U.S.A. 77:7347-7351.

Ditta, G., Schmidhauser, T., Yakobson, E., Lu, P., Liang, W. X., Findlay, D. R., Guiney, D. and Helinski, D. R. 1985. Plasmids related to the broad host range vector, pRK290, useful for gene cloning and monitoring gene expression. Plasmid 13:149-153

Dookun, A., Saumtally, S., and Seal, S. 2001. Genetic diversity in Ralstonia solanacearum strains from Mauritius using restriction fragment length polymorphisms. J. Phytopathol. (Phytopathol. Z.) 149:51-55.

Fenselau, S., and Bonas, U. 1995. Sequence and expression analysis of the $h r p B$ pathogenicity operon of Xanthomonas campestris pv. vesicatoria which encodes eight proteins with similarity to components of the Hrp, Ysc, Spa, and Fli secretion systems. Mol. Plant-Microbe Interact. 8:845-854.

Feschotte, C., and Mouches, C. 2000. Evidence that a family of miniature inverted-repeat transposeable elements (MITEs) from the Arabidopsis thaliana genome has arisen from a pogo-like DNA transposon. Mol. Biol. Evol. 17:730-737.

Feschotte, C., Jiang, N., and Wessler, S. R. 2002. Plant transposable elements: Where genetics meets genomics. Nature Rev. 3:329-341.

Fortnum, B. A., and Martin, S. B. 1998. Disease management strategies for control of bacterial wilt of tobacco in the southeastern USA. Pages 394-402 in: Bacterial Wilt Disease: Molecular and Ecological Aspects. P. Prior, C. Allen, and J. Elphinstone, eds. Springer-Verlag, Berlin Heidelberg.

Gabriel, D. W. 1999. Why do pathogens carry avirulence genes? Physiol. Mol. Plant Pathol. 55:205-214.

Gillings, M., and Fahy, P. 1993. Genetic diversity of Pseudomonas solanacearum biovar 2 and biovar N2 assessed using restriction endonuclease analysis of total genomic DNA. Plant Pathol. 42:744-753.

Guttman, D. S., Vinatzer, B. A., Sarkar, S. F., Ranall, M. V., Kettler, G., and Greenberg, J. T. 2002. A functional screen for the type III (Hrp) secretome of the plant pathogen Pseudomonas syringae. Science 295:1722-1726.

Horita, M., and Tsuchiya, K. 2001. Genetic diversity of Japanese strains of Ralstonia solanacearum. Phytopathology 91:399-407.

Jack, A. M., and Robertson, A. E. 1997. Sub-group collaborative study on bacterial wilt (Ralstonia solanacearum)-1997 report. Pages 15-22 in: Information Bulletin. Cooperation Centre for Scientific Research Relative to Tobacco (CORESTA), Paris. 
Jackson, R. W., Athanassopoulos, E., Tsiamis, G., Mansfield, J. W., Sesma, A., Arnold, D. L., Gibbon, M. J., Murillo, J., Taylor, J. D., and Vivian, A. 1999. Identification of a pathogenicity island which contains genes for virulence and avirulence, on a large native plasmid in the bean pathogen Pseudomonas syringae pathovar phaseolicola. Proc. Natl. Acad. Sci. U.S.A. 96:10875-10880.

Jiang, N., Z. Bao, X. Zhang, H. Hirochika, S.R. Eddy, S.R. McCouch and S.R. Wessler. 2003. An active DNA transposan family in rice. Nature 421:163-167.

Kearney, B., and Staskawicz, B. J. 1990a. Characterization of IS476 and its role in bacterial spot disease of tomato and pepper. J. Bacteriol. 172:143-148.

Kearney, B., and Staskawicz, B. J. 1990b. Widespread distribution and fitness contribution of Xanthomonas campestris avirulence gene avrBs2. Nature (Lond.) 346:385-386.

Kearney, B., Ronald, P. C., Dhalbeck, D., and Staskawicz, B. J. 1988. Molecular basis for evasion of plant host defense in bacterial spot disease of pepper. Nature (Lond.) 332:541-543.

Kelman, A. 1953. The bacterial wilt caused by Pseudomonas solanacearum, Tech. Bull., N. Carolina Agric. Exp. Stn. Agricultural Experiment Station, North Carolina State College, Raleigh.

Kelman, A., and Person, L. H. 1961. Strains of Pseudomonas solanacearum differing in pathogenicity to tobacco and peanut. Phytopathology 51:158-161.

Kjemtrup, S., Nimchuk, Z., and Dangl, J. 2000. Effector proteins of phytopathogenic bacteria: Bifunctional signals in virulence and host recognition (Review). Curr. Opin. Microbiol. 3:73-78

Kousik, C. S., and Ritchie, D. F. 1996. Race shift in Xanthomonas campestris pv. vesicatoria within a season in field-grown pepper. Phytopathology 86:952-958.

Leach, J. E., and White, F. F. 1996. Bacterial avirulence genes. Annu. Rev. Phytopathol 34:153-179.

Lorang, J. M., Shen, H., Kobayashi, D., Cooksey, D., and Keen, N. T. 1994 AvrA and AvrE in Pseudomonas syringae pv. tomato Pt23 play a role in virulence on tomato plants. Mol. Plant-Microbe Interact. 7:508-515.

Lucas, G. B. 1975. Tobacco Diseases. 3rd ed. Biological Consulting Associates, Raleigh, NC.

Mahillon, J., and Chandler, M. 1998. Insertion Sequences. Microbiol. Mol. Biol. Rev. 62:725-774.

Mahillon, J., Leonard, C., and Chandler, M. 1999. IS elements as constituents of bacterial genomes. Res. Microbiol. 150:675-687.

Mazzone, M., De Gregaorio, E., Lavitola, A., Pagliarulo, C., Alfano, P. and Di Nocera, P. P. 2001. Whole-genome organization and functional properties of miniature DNA insertion sequences conserved in pathogenic Nesseriae. Gene 278:211-222.

Michel, V. V., Hartman, G. L., and Midmore, D. J. 1996. Effect of previous crop on soil populations of Burkholderia solanacearum, bacterial wilt, and yield of tomatoes in Taiwan. Plant Dis. 80(12):1367-1372.

Oggioni, M. R., and Claverys, J. P. 1999. Repeated extragenic sequences in prokaryotic genomes: A proposal for the origin and dynamics of the RUP element in Streptococcus pneumoniae. Microbiology 145:26472653.

Petnicki-Ocwieja, T., Schneider, D. J., Tam, V. C., Chancey, S. T., Shan, L., Jamir, Y., Schechter, L. M., Janes, M. D., Buell, C. R., Tang, X., Collmer, A., and Alfano, J. R. 2002. Genomewide identification of proteins secreted by the Hrp type III protein secretion system of Pseudomonas syringae pv. tomato DC3000. Proc. Natl. Acad. Sci. U.S.A. 99:7652-7657.

Poussier, S., Vandewalle, P., and Luisetti, J. 1999. Genetic diversity of African and worldwide strains of Ralstonia solanacearum as determined by PCR-restriction fragment length polymorphism analysis of the hrp gene region. Appl. Environ. Microbiol. 65:2184-2194.

Poussier, S., Thoquet, P., Trigalet-Demery, D., Barthet, S., Meyer, D. Arlat, M. and Trigalet, A. 2003. Host plant-dependent phenotypic reversion of Ralstonia solanacearum from non-pathogenic to pathogenic forms via alterations in the phcA gene. Mol. Microbiol. 49:991-1003.

Prior, P., and Steva, H. 1990. Characteristics of strains of Pseudomonas solanacearum from the French West Indies. Plant Dis. 74:962-965

Prior, P., Grimault, V., and Schmit, J. 1994. Resistance to bacterial wilt (Pseudomonas solanacearum) in tomato: Present status and prospects. Pages 209-224 in: Bacterial Wilt: The Disease and Its Causative Agent, Pseudomonas solanacearum. G. L. Hartman, ed. CAB International, Wallingford, UK.

Redder, P., She, Q., and Garrett, R. A. 2001. Non-autonomous mobile elements in the crenarcheon Sulfolobus solfataricus. J. Mol. Biol. 306:1-6.

Robertson, A. E., Fortnum, B. A., Wood, T., and Kluepfel, D. 2001. Diversity of Ralstonia solanacearum in the Southeastern United States. Beitr. Tabakforsch. Int./Int. Contrib. Tobacco Res. 19:319-327.

Salanoubat, M., Genin, S., Artiguenave, F., Gouzy, J., Mangenot, S., Arlat, M., Billault, A., Brottier, P., Camus, J. C., Cattolico, L., Chandler, M., Choisne, N., Claudel-Renard, C., Cunnac, S., Demange, N., Gaspin, C., Lavie, M., Moisan, A., Robert, C., Saurin, W., Thébault, P., Schiex, T., Siguier, P., Whalen, M., Wincker, P., Levy, M., Weissenbach, J., and Boucher, C. A. 2002. The genome sequence of the wide host-range plant pathogen Ralstonia solanacearum. Nature 415:497-502.

Sambrook, J., Fritsch, E. F., and Maniatis, T. 1989. Molecular Cloning: A Laboratory Manual. 2nd ed. Cold Spring Harbor Laboratory Press, Cold Spring Harbor, NY.

Shaner, G., and Finney, R. E. 1977. The effect of nitrogen fertilization on the expression of slow-mildewing resistance in Knox wheat. Phytopathology 67:1051-1056.

Smith, J. J., Offord, L. C., Holderness, M., and Saddler, G. S. 1995. Genetic diversity of Burkholderia solanacearum (Synonym Pseudomonas solanacearum) race 3 in Kenya. Appl. Environ. Microbiol. 61:4263-4268.

Stevens, C., Bennett, M. A., Athanassopoulos, E., Tsiamis, G., Taylor, J. D., and Mansfield, J. W. 1998. Sequence variations in alleles of the avirulence gene avrPphE.R2 from Pseudomonas syringae pv. phaseolicola lead to loss of recognition of the AvrPphE protein within bean cells and a gain in cultivar-specific virulence. Mol. Microbiol. 29:165-177.

van't Slot, K. A. E., and Knogge, W. 2002. A dual role for microbial pathogen-derived effector proteins in plant disease and resistance. Crit. Rev. Plant Sci. 21:229-271.

Vivian, A., and Gibbon, M. J. 1997. Avirulence genes in plant-pathogenic bacteria: Signals or weapons? Microbiology (UK) 143:693-704.

White, F. F., Yang, B., and Johnson, L. B. 2000. Prospects for understanding avirulence gene function. Curr. Opin. Plant Biol. 3:291-298.

Yang, B., Zhu, W., Johnson, L. B., and White, F. F. 2000. The virulence factor AvrXa7 of Xanthomonas oryzae pv. oryzae is a type III secretion pathway-dependent nuclear-localized double-stranded DNA-binding protein. Proc. Natl. Acad. Sci. U.S.A. 97:9807-9812.

\section{AUTHOR-RECOMMENDED INTERNET RESOURCES}

EMBnet ClustalW website: www.ch.embnet.org/software/ClustalW.html INRA (Institute for Agronomy Research) Ralstonia solanacearum GMI1000 website: sequence.toulouse.inra.fr/R.solanacearum.html

IS Finder website: www-is.biotoul.fr/

Kazusa DNA Research Institute Codon Usage database: www.kazusa.or.jp/codon/

National Center for Biotechnology Conserved Domain database search: www.ncbi.nlm.nih.gov/Structure/cdd/wrpsb.cgi 